\title{
First Aerial South Atlantic Night Crossing
}

\author{
Fernando Neves, Jorge Barata, André Silva \\ Aerospace Sciences Department, University of Beira Interior, Covilhã, Portugal \\ Email:fernandomneves@gmail.com
}

Received 13 January 2016; accepted 7 March 2016; published 10 March 2016

Copyright (C) 2016 by authors and Scientific Research Publishing Inc.

This work is licensed under the Creative Commons Attribution International License (CC BY). http://creativecommons.org/licenses/by/4.0/

(c) (i) Open Access

\section{Abstract}

The history of the transatlantic flights began in 1919 when Albert C. Read's team flew between Newfoundland and Lisbon, with a stopover at Azores, for fuel and repairs. The flight was made following a chain of $60 \mathrm{U}$.S. warships in order to guide it along its route and to provide assistance if needed. Two weeks later, John Alcock and Sir Arthur Whitten Brown made the first nonstop transatlantic flight from Newfoundland to County Galway, Ireland, covering more than 3000 km in just 16 hours of flight. In 1922, Gago Coutinho and Sacadura Cabral crossed the South Atlantic Ocean by air, for the first time using only internal means of navigation: a modified sextant and a course corrector; both devices proved its effectiveness. The Portuguese Aeronautics rejoiced auspicious days that time, with its aviation pioneers trying consecutively to reach more distant places along intercontinental flights. Several Around-the-World Flight Attempts were made in 1924: United States, England, France, Portugal, Argentina and Italy. However the circumnavigation purpose was only officially confirmed before the general public, when a considerable flying progress was achieved. In 1923, Gago Coutinho and Sacadura Cabral were contemplating to perform an Around the World Flight, a dream pursued also by Sarmento de Beires in 1924 and 1927. In 1927 and by following the knowledge obtained by Coutinho and Cabral, four Portuguese Airmen started an Around the World Flight Attempt in a mission that ended with seaplane sunk at the Ocean; however this mission was renamed after the seaplane loss and became known in the World as the First Aerial South Atlantic Night Crossing. For the first time in history, during the night of 16 to 17 March 1927, a Portuguese crew flew $2595 \mathrm{~km}$ over the Atlantic Ocean from Guinea, Africa to Fernando de Noronha Island, Brazil. The flight was made only by astronomical processes navigation resources that proved again to be absolutely feasible and trustworthy, regardless day or night lighting conditions.

\section{Keywords}

Admiral Gago Coutinho Sextant, Astronomical Navigation, History of Night Flying 


\section{Portugal's Aerial Navigation Background History}

The pioneer of aeronautics in Portugal was a Jesuit monk, Bartolomeu de Gusmão, who interrupted his studies at Coimbra University to develop his flying machines (Figure 1(a)). On 5 and 8 August 1709, the monk demonstrated the principle of lighter-than-air to the King John V of Portugal, to his court and to the Papal Representative Conti (later to become Pope Inocencius XIII). Gusmão demonstrated indoors and outdoors the principle using a "hot air balloon" that in one case reached a height of 4.5 meters, and made drawings of a "Passarola" (a bird-like flying ship-Figure 1(b)). Since that time, the ideas of aeronautics conceptions were exclusively dominated by lighter-than-air airships which served a great variety of purposes till the $20^{\text {th }}$ Century. The first airplane flew in Portugal in 1909. The Portuguese contribution of an expeditionary force in France during World War I marked the beginning of military aviation in Portugal. From 30 March to 17 June 1922, Gago Coutinho and Sacadura Cabral flew a Fairey hydroplane from Lisbon to Rio de Janeiro in the first crossing of the South Atlantic (Albuquerque, 1989; Corrêa, 1964, 1969; Cardoso, 1981; Barata et al., 2009; Silva et al., 2009; Neves et al., 2010a, 2010b; Reis \& Cortesão, 1969). This was the first flight conceived by astronomical and estimated navigation means, with the help two devices, namely, a modified Navy sextant and a course corrector (Cabral, 1921), both developed by Coutinho and Cabral. After this trip, Sacadura Cabral decided to conceive and organize a circumnavigation air journey (Corrêa, 1964; Cardoso, 1981; Neves et al., 2010b; Neves et al., 2016), which he admitted that had to be firstly done by the Portuguese, not only for historical reasons, i.e., to repeat Fernão de, as well as for foreign and domestic political reasons (Fernão de Magalhães; Sabrosa, Portugal, spring of 1480- Cebu, Philippines, 27 April 1521, was a Portuguese explorer who became known for having organized and commanded the maritime expedition of the First Earth Circumnavigation). However, from 17 March to 28 September 1924, four teams of American navigators held the first air circumnavigation journey (Corrêa, 1964). Sadly, on 15 November 1924, Cabral died somewhere at the English Channel while piloting a Fokker T-III.W model, from Amsterdam to Lisbon, one of five airplanes that he acquired by public subscription with the intent to start an air travel to India as a beginning of a circumnavigation journey (Journal Flight, 1923: p. 551). Sacadura had foreseen the future of air transports. The desire of a circum navigating air travel was also at Brito Pais and Sarmento de Beires imagination: with Manuel Gouveia mechanical attendance, these airmen flew more than half around the World distance, from Lisbon to Macau from 7 April to 20 June 1924 (Beires, 1953; Cardoso, 1981).

\section{Improvements into the Sextant "System Admiral Gago Coutinho"}

After the First Crossing of the South Atlantic, Gago Coutinho worked almost daily in perfecting his sextant and began to share with Jorge Castilho all the improvements that might be introduced in that device. This subject would be of Castilho's particular interest since a long Portuguese Aerial Journey was being prepared by Sarmento de Beires where as Castilho should be invited as a navigator and would use the Sextant "System Admiral Gago Coutinho" (Correa, 1969). In 1926 Sarmento de Beires presented to the Direcção da Arma de Aeronáutica [Portuguese Directorate of Military Aeronautics] a meticulous and detailed study proposal in order to conduct an aerial circumnavigation. Jorge Castilho thus became the applied disciple of Gago Coutinho, himself introducing
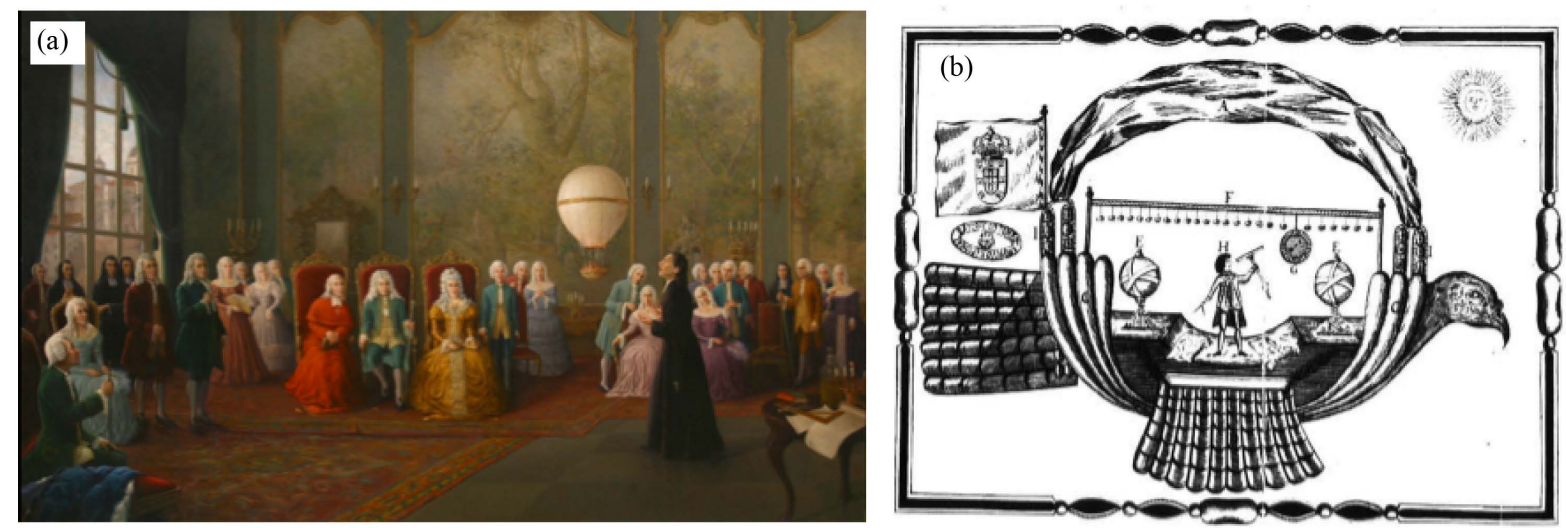

Figure 1. (a) Painting of Bartolomeu de Gusmão begging a privilege to the King for his invention; (b) A "Passarola" drawing. 
some improvements to Coutinho's sextant, later manufactured by the Hughes house, London (Cardoso, 1981). The improvements were namely: build a left-handed sextant, freeing thus the right hand for immediate an notation of heights and time, eliminating all memory resources; a special lunette inclusion for stargazing, making the device suitable for more stringent observations and maintaining its scientific certainty during all 24 hours of the day; the detection of a star (or a planet) and its respective adjustment became made simultaneously with a single screw, by the inclusion of a screw adjustment step (Beires, 1927). In 1926, Jorge Castilho performed several flights in order to rehearse and to put in practice the methods and devices of celestial navigation. For that purpose on 8 March 1926 Sarmento de Beires, Pais Ramos, Jorge Castilho and Manuel Gouveia, taken off in two aircrafts Napier Vickers and flew Amadora-Morocco-Amadora. In addition to testing the sextant, the four hundred kilometers to each side of this trip most of the time without land sighting revealed that Jorge Castilho possessed the required competence for long range flights (Beires, 1927).

\section{Sarmento de Beires Motivations}

In 1924, Sarmento de Beiress hared already of the monumental Sacadura Cabral's dream-the Around World Flight Travel. Later, by his readings (Dollfus \& Hirschauer, 1925-1926) Beires had the opportunity to verify an accomplishment of dozens aerial long journeys along the year 1926. All these journeys were taken by nations who reported high relevance and an indomitable will to the Aeronautics. At the year 1927, Beires found an upsurge of Aeronautics same nature activity. Whilst acknowledging that the tempting objectives were thinning, he realized that the Aeronautical ventures would not cease because after the unreleased performances challenges an interesting international exchange phase will come, before reaching the commercial viability, comparable to that of shipping those days. By this vision, Beires recognized that all airplanes manufacturer Countries would have a very special advantage in promoting long trips. In fact he verified that this situation would not be of politically interesting for all countries. He knew that the air travels subject was unquestionably the biggest national propaganda factor of the $20^{\text {th }}$ century. Confirming this hypothesis, there was the example of all the countries that guided its aeronautical activity accordingly to that purpose and on which they also spent consider able budgetary allocation to the Aeronautics, as Spain, France, Italy, North America and Russia (Beires, 1927). On those days and by facing this issue under Portuguese national aspects, Sarmento de Beires thought unjustifiable that the political power did not fore saw that Portugal and its colonies (Sao Tomé and Principe, Guinea, Angola, Mozambique, Timor, Goa, Macau) would benefit from a strategic colossal power, by the possibility of military and commercial air travels between all these Portuguese territories, including also a special assignment to Brazil even as an extension of Portuguese interests (Beires, 1927).

\section{Preliminary Draft of the Around the World Flight by Sarmento de Beires}

On 15 December 1924 Sarmento de Beires reread the report of its Lisbon-Macau air travel in 1924 and his memory revived the idea of participating in an Around World Flight Travel. From 10 to12 January 1925 and by following the Fernão de Magalhães route at a World chart map, he reflected on possible stages that would have to be taken. All the chosen stopovers would have to be less than $3000 \mathrm{~km}$ distance due to the restrictions of all aircrafts at that time. Thus he devised one route: Portugal, India, Timor, Australia, Oceania, Chile, Brazil, Cape Verde and Portugal. This route crossed the vastness of the Pacific Ocean near the equator line. To follow this route, he would have to be sure that both Sala y Gómez $\left(26^{\circ} 28^{\prime} \mathrm{S} 105^{\circ} 28^{\prime} \mathrm{W}\right)$ and Phoenix Islands $\left(02^{\circ} 50\right.$ 'S $171^{\circ} 43^{\prime} \mathrm{W}$ ) would offer stopover conditions. In August 1925 he visited the Potez facility at Méaulte, France, in search for suitable airplanes to use on a trip of this nature (Aéroplanes Henry Potez-French aircraft manufacturer established in 1919 by Henry Potez and acquired in 1967 by Sud-Aviation). On 16 February 1926, Sarmento de Beires started writing a preliminary draft for a trip around the world that included the main requirements: an aircraft for the trip; the required crew; all stages and stopover locations; total monetary costs and the refueling stations that had to be organized Around the World. On 19 February this document was delivered for appraisement at the Inspeç̧ão de Aeronáutica Militarna Direç̧ão da Arma de Aeronáutica [Military Aeronautical Board of Inspectors at the Directorate of Aeronautics Weapon]. On 3 March the document was discussed by the Technical Committee of the Directorate of Aeronautics Weapon which transmitted a concurring opinion. On 10 March a copy of this document was send off to the War Ministry Cabinet Office. On 7 Maya meeting was held on which was widely discussed once for all, the technical features of the airplane to choose. The frequent replacement of wheels by floats was not accepted due to the difficulty and the floats hardness was considered 
questionable. The final airplane option considered for use was a metal boat-hull fuselage seaplane (Figure 2). The technical discussion about the power plant was decided in favour of a Lorraine Dietrich twin-engine seaplane. After anew briefing round with manufactures representatives the chosen seaplane was a modified (by request) Dornier-Wal model, manufactured by the German company, Dornier Flugzeugwerke (German aircraft manufacturer founded at Friedrichshafen in 1914 by Claudius Dornier and acquired in 1996 by Fairchild Aircraft, forming Fairchild Dornier; the company went bankrupt in 2002). By the Directorate of Aeronautical Weapon request, Sarmento de Beires proceeded to several modifications as necessary and tried to complement the initial preliminary draft program. The document was improved with a section regarding the best annual weather conditions for the crossing of the Atlantic and Pacific Oceans, as well as for the Oceania, India and Mediterranean Sea. Another added section concerned all means of the navigation processes to use during all flight time, with a particular negligence for radio-goniometry (TSF), once the crew intended to demonstrate the superiority of the Portuguese navigation methods used by Coutinho and Sacadura in 1922. On 8 June the modified preliminary draft was again endorsed to the Technical Committee which transmitted again a favorable opinion, yet still reserving the right to propose amendments if necessary. Meantime the journey route was modified to follow the clockwise direction due the prevailing winds. This new route would have three main legs. The first leg should involve the crossing of the Atlantic, Brazil, Argentina, to Chile in a distance of $12,000 \mathrm{~km}$. The second leg involved the crossing of the Pacificvia Tahiti, Australia, Timor, with a four days stop for engines replacement. The longest stage $(3084 \mathrm{~km})$ should be from the Juan Fernandez Island $\left(33^{\circ} 38^{\prime} \mathrm{S} 78^{\circ} 49^{\prime} \mathrm{W}\right)$ to the Easter Island $\left(27^{\circ} 7^{\prime} \mathrm{S} 109^{\circ} 22^{\prime} \mathrm{W}\right)$. The third leg should involve the trip to Singapore, Ceylon (actual Sri Lanka), Goa, Karachi, Bushehr, Alexandretta (actual İskenderun), Bizerta and Lisbon. On 14 June the Military Aeronautical Board of Inspectors requested to the Ministry of War Cabinet the monetary funds to carry out the journey. Three weeks later on 5 July 1926, the Minister of War decided to cancel the entire project. The prior approval of the preliminary draft and all subsequent discussions and amendments had already led to several legal commitments insured with some manufacturers. Furthermore, France, Germany, Italy and England already had the journey completion knowledge. Finally on 23 July the Ministry of War issued an unofficial statement saying that the Portuguese Government had authorized the completion of the journey Around the World. The Dornier manufacturer based much of its seaplanes production in its factories located at Marinadi Pisa, Italy. On 30 December 1926 and with the Portuguese crew onboard the seaplane was tested with various propellers types. Between 11 and 14 January 1927, the crew held four stages on their way to Portugal: Marinadi Pisa, Barcelona, Los Alcazares, Malaga and Alverca, flying a total of $2630 \mathrm{~km}$ (Beires, 1927); meantime the British press publicly announced the Portuguese Around the World Flight intention (Journal Flight, 1927a: p. 98).

\section{Crew Biographical Notes}

The First Night Aerial Crossing of the South Atlantic was made in a Portuguese Army Aviationtwin-engine
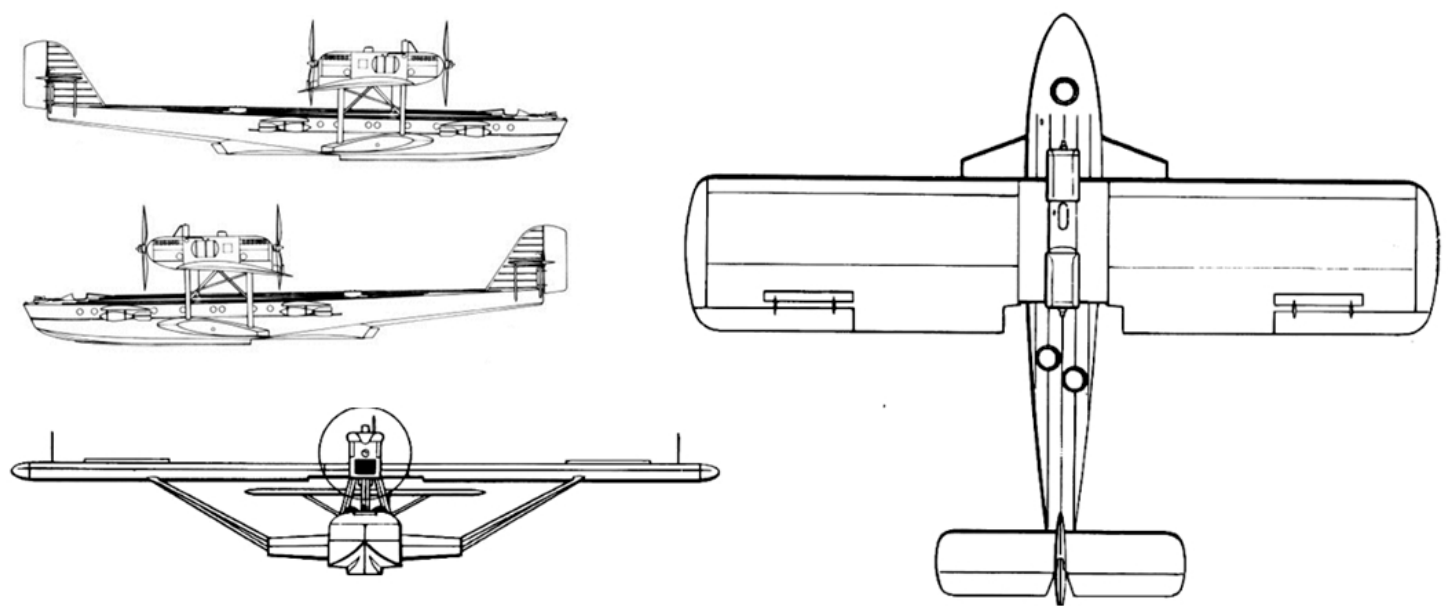

Figure 2. Four technical drawing views of the chosen seaplane Dornier DO J Wal; in 1927 the seaplane was prepared to use sets of propellers with different numbers of blades, depending on a proper calibration. 
Lorraine-Dietrich 450 hp metallic seaplane Dornier Do J Wal named “Argos”. Its crew included the pilot Sarmento de Beires, the co-pilot Duvalle Portugal, the navigator Jorge Castilho and the mechanic Manuel Gouveia. Sarmento de Beireswas the main architect and organizer of this journey.

\subsection{José Manuel Sarmento de Beires}

José Manuel Sarmento de Beires (Lisbon, 04 September 1892-Oporto, 08 June 1974) became a Military College student and in 1916 he completes the course of military engineer in the School of War. In 1917 with the rank of Ensign, he completed successfully the first course of military pilot held at Portugal. In July 1917, he was promoted to the rank of lieutenant and went to France, integrated at the Aviation Services of CEP (Corpo Expedicionário Português-Portuguese Expeditionary Corps). In France he attended training courses, specializing in fighter aviation. In 1919 he returned to Portugal integrated in the Grupo de Esquadrilhas de Aviação República [Squadrons Group of Republic Aviation]. In 22 January 1920 Sarmento Beires became the first Portuguese pilot to perform a night flight mission. Also in 1920 along with Brito Pais, he tries an unsuccessful direct trip attempt to Madeira Islands aboard the hydroplane Breguet XIV A2, named "Cavaleiro Negro". In 1924, he flew the Raid Lisbon-Macau with Brito Pais and Manuel Gouveia, in a journey that lasted from 7 April to 24 July. This Journey became known in the World as the First Aerial Raid from Portugal to Macau was in fact the first Portuguese attempt to fly Around the World. Due to the range of some stages during the South Atlantic Cross in this new Journey, Sarmento de Beires emerged the need to recruit a co-pilot, chosen by its demonstrated competence (Cardoso, 1981).

\subsection{Alfredo Duvalle Portugal}

Captain Alfredo Duvalle Portugal which had also attended the first course of military pilot held at Portugal in the Aeronautical Military School at Vila Nova da Rainha in 1916-1917, was chosen for the co-pilot. This first year pilot course recorded 20 pilot candidates. Captain Alfredo Duvalle Portugal was classmate of Sarmento de Beires (Cardoso, 1981).

\subsection{Jorge Vidal de Castilho Barreto e Noronha}

Jorge Vidal de Castilho Barreto e Noronha (Lisbon, 23 May 1882-Melbourne, Australia, February 1943) studied engineering at the University of Louvain, Belgium, but in 1902 he returned to Lisbon with an uncompleted course. At Lisbon he became integrated as a cadet at Cavalry 2 and joined the Escola do Exército [Army School] where hesuccessfully completed the Infantry Officer Course. In 1906 he was promoted to the rank of Ensign and joined the $11^{\text {th }}$ Infantry Regiment at Setúbal. In June 1908 he was sent to Lourenço Marques, (actually known as Maputo) Mozambique integrated as the General Governor adjunct. Also at Mozambique he began to work at a Border Mission delimitation headed by the Commander Gago Coutinho, where he became familiarized with use of the sextant. Returning to Portugal in 1909 he was sent to Guimarães. In May 1910 he was appointed Governor of the Damandistrict, India, from where he returned to Portugal with a rank of Lieutenant in April 1914. Due to Republic Implantation happening at Portugal, Jorge Castilho (staunch monarchist) asked for an unlimited license and went to live at Brazil, where he devoted himself to teaching at Rio de Janeiro. Meanwhile, the World War I started and he presented himself to the Portugal's duty services. In June 1916 he was sent to Mozambique integrated in expeditionary companies. He was promoted to Captain in September 1916 and returned to Lisbon in December 1917. In early 1918 he was sent to CEP at France until May 1919. In 1920, Jorge Castilhocomesto lead themagazine "O Automóvel”, where his enginesand electricity power knowledge allow him towriteinterestingarticles. At the same time hebegins toaddress aeronautical issues, writing articles onthe $1^{\text {st }}$ attemptair travelto Madeira, carried outin October1920 by Sarmento Beires and Brito de Pais. On 10 November 1925 Sarmento de Beires invited Jorge Castilho to collaborate in this journey as the air navigator (Cardoso, 1981).

\subsection{Manuel António Gouveia}

Manuel António Gouveia (Oporto, 04 February 1890-Lisbon, 10 December 1966) in 1912 became working at Companhia de Caminhos de Ferro, at Cova da Moura, Lisbon. In 1917, he was mobilized for France where he joined the Portuguese Expeditionary Corps. Also at France, captain pilot aviator Norberto Guimarães who led 
the Portuguese Aviation Military service, invited him to join the Portuguese Air Force. Manuel Gouveia attended both the Mechanical School of Saint Cyr and the Gnome-Rhône factories, (Gnome-Rhône was a major French aicraft engine manufacturer, predecessor of Snecma), working finally for the aircraft factory HispanoSuiza in France. (Hispano-Suiza was a Spanish automotive and engineering firm founded at 14 June 1904. In 1970 became a subsidiary ofSnecma). He was also invited to be part of a team in order to acquire material in France, and thus to prepare a new aircraft unity Squadronat Amadora. He returned to Portugalin December 1919 and was appointed chief mechanic of the SPAD S.VII Squadron at Amadora. (S.VII was a highly successful biplane fighter aircraft produced by Société Pour L'Aviation etses Dérivés-SPAD). Later he was invited by Brito Pais and Sarmento de Beires to become part and to complete the crew in a journey from Lisbon to Macau in 1924. On 10 November 1925 Sarmento de Beires invited Manuel Gouveia to collaborate in this journey as the mechanic. In 1926, he became graduated pilot in the Military Aviation Schoolat Sintra, Portugal (Cardoso, 1981).

\section{Navigational Devices Onboard the Seaplane "Argos"}

The navigation devices list aboard the "Argos" was quite full: chart maps, magnetic compass, heliograph, tachymeter, derivómetro, Badin tachometer, altimeter, chronometer, sextant, protractors, rulers, compasses, books and tables. Some of these devices were manufactured in a rudimentary form and during its flight uses revealed a dubious usefulness and were removed. During this flight the crew practiced both estimated and astronomical navigation. While flying by estimated navigation the estimated point was previously marked on the chart map calculated by the course followed and the space traversed depending on the speed of the airplane and the flight time. In order to retrieve from the wind drift the crew used a prepared in advance table instead of the course corrector. While flying by celestial navigation the only process used was the "recta das Alturas" height straight-line. The height "altura" of the observed planet or star was estimated by the Ball tables and azimuth was searched at the Davis tables (Cardoso, 1981). Figure 3 illustrates some navigation devices onboard the "Argos".

\subsection{Chart Maps}

The crew members had various chart maps types to consult according to their required needs: general coastal chart maps in the Mercator projection, port chart maps and conical-secant chart maps for celestial navigation use. The general chart maps used were provided from the British Admiralty and also from the French Hydrographic Service. The French Hydrographic Service chart maps had the disadvantage of having gridlines along the Paris meridian; for this navigation course the use of the Greenwich meridian was favored, from which all chronometers onboard were regulated. The pilots consulted basically large scale chart maps on which little details could not be observed. These chart maps were used for the airplane positioning during a long range stage. For the navigation service the navigators used more detailed chart maps where they could manage to follow the airplane's course as well to calculated directions and distances. The navigational chart maps collection onboard encompassed all routes. Related with this item, for this journey the airplane was carrying enough chart maps information

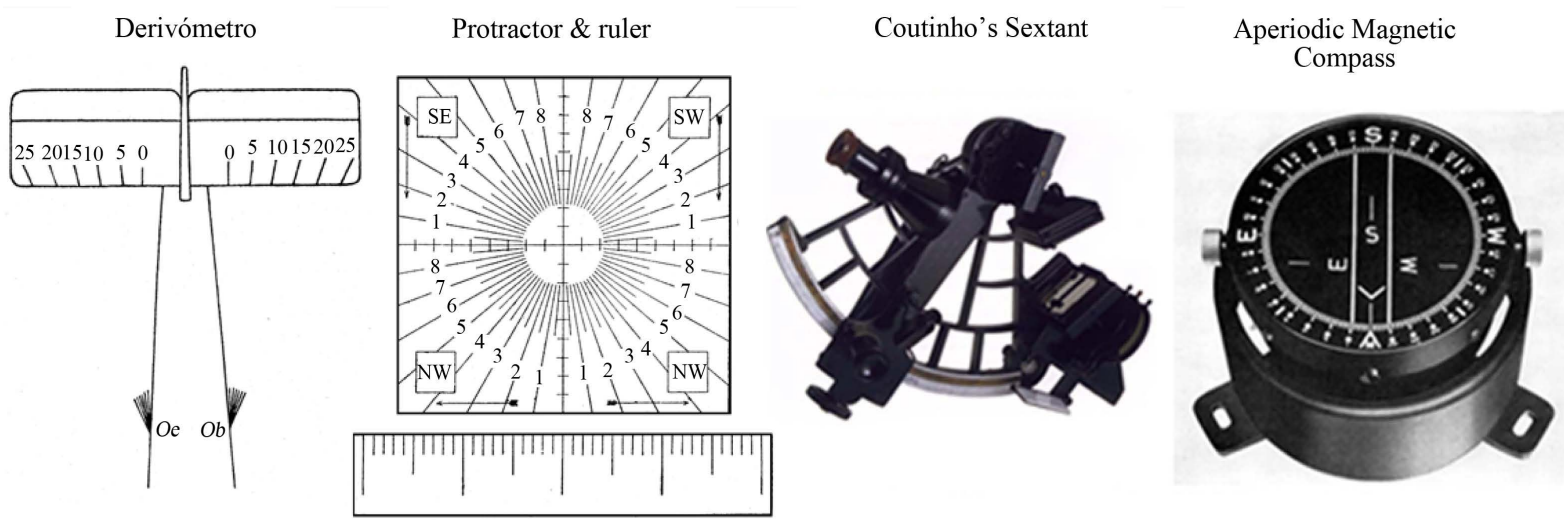

Figure 3. List of several navigation most useful devices onboard the seaplane "Argos"; Derivómetro; Protractor and ruler; “System Admiral Gago Coutinho’s” Sextant and an Aperiodic Magnetic Compass. 
that enabled the crew for a circumnavigation aerial journey (Cardoso, 1981). The collection of ports and bays chart maps was also extensive and included all the alternative cases, if necessary.

\subsection{Magnetic Compass}

From several gender devices onboard, during the flights the most used was the aperiodic magnetic compass Hughes, type 6/18 Mark III, provided with a grid ring divided every $2^{\circ}$. This ring was rotatable and could be fixed by two clamps at any required direction. This grid ring drags a four wires reticulum parallel to each other at the $0^{\circ}-180^{\circ}$ diameter. The maneuver of the pilot in order to maintain and follow the flight course, was to keep the rods parallel to the train guide reticulum grid ring, not fearing parallax errors, whatever the observed position. The aircraft framing almost all aluminum dismissed the use of compensating compass bar, with a single required need to organize a deviations table, which never went beyond $2^{\circ}$.

\subsection{Heliograph}

For the pilot's convenience in its arduous task of follow strictly the flight course with precision, it was invented a small instrument called heliograph, in lack of a better name. This device consisted simply in a mirror assembled so as to allow its rotation around the two perpendicular axes. The device was than assembled at the aircraft cockpit into a fixed Sun exposed position. The main idea of this device was to keep the airplane's course constant only by the seemingly simple move of the mirror until the Sun's reflection image appears reflected on a vertical hair stroke done at the dashboard. This device was later removed due to its bad installation which provided coarse results.

\subsection{Tachymeter}

The tachymeter used in the flights was built at Portugal and consisted in an aluminum plate fixed at the seaplane's prow in such a position that the faith line written on the device remained parallel to the apparatus axis. On top of that plate moves a limbo with an every $10^{\circ}$ graduation from $0^{\circ}$ to $360^{\circ}$. The diameter of this limbo consisted in a graduated brass ruler, showing at one end a pinnule positioned perpendicularly to the limbo plan. During the flight the pilot would have to coincide both the airplane and needle's axis; the next step was to fix the brass ruler in coincidence with the graduation limbo, corresponding South azimuth. Then he twirled the limbo until the pinnule shadow came to light on the brass ruler. This procedure was repeated for each and every different course direction. The graduation limbo at that exact time corresponded to the plate's faith line and was in fact the true course direction followed. The difference between this direction and the direction of the needle corresponded to the total error, given by the needle.

\subsection{Derivómetro}

Aboard the "Argos", the wind drifts were always s measured according to the procedure provided by the Admiral Gago Coutinho in his travels, which uses a graduation scale made at the stabilizer tail section. $\mathrm{Be} O b$ and $O e$ two points at the starboard and portside of the airplane where the observers were placed. The points $0,5,10$, $15 \ldots$ marked by lines at both sides of the stabilizer will be such that both lines $O b O$ and $O e O$ were parallel to the airplane axis. Therefore the lines $O e 5, O b 10, O e 15$, will form angles of 5, 10, and 15 on both sides with this axis. While in flight, with no wind, headwind or tailwind conditions any reference in the ground that passes at the $O b$ and $O e$ vertical has its tail stabilizer projection over the graduation 0 , meaning null wind drift. If the ground fixed protrudes on any of the lines of $5,10,15 \ldots$, then this means that the existing wind causes adrift of $5,10,15 \ldots$ on that side. This device was considered extremely simple and had the advantage of being able to observed rift of only $1^{\circ}$ (if the pilot could fly with such accuracy). Traveling over land was always possible to reference ground references that pass vertically by $\mathrm{Ob}$ and $\mathrm{Oe}$ points. However, by traveling over the ocean these references do not exist and have to be created artificially, with the aid of buoys (with smoke when used during the day; with firelight at night). These buoys were launched by the observers into the sea. Due to the small heights of the airplane during its flight, the error of direction that came from the fall time of the buoy to the sea was despised. The weight of each buoy $(0.5 \mathrm{~kg})$ and the number of buoys required for each stage disfavored the capacity of fuel onboard. This problem was solved later by replacing the buoys for airtight cylindrical boxes containing $20 \mathrm{~g}$ of calcium phosphide. During the night these boxes produced enough light that allowed 
wind drift measurements. When used, these boxes were stuck on both sides in order to allow the phosphide contact with sea water (inflammation). The buoys were thrown overboard wrapped in cork, so that they can float.

\subsection{Badin Tachometer}

During the flights all the onboard problems were involved in global problem: the velocity estimation of the airplane. Unfortunately, the "Argos" was not really provided with a velocity indicator of the aircraft speed relative to the air. For this purpose, there was onboard a device brought from Italy-Badin System-which become unusable at Villa Cisneros, probably due to sand clouds at that region. Therefore, all velocity estimations made were provided with a basilar defect. But the all the crew's confidence in celestial navigation was unshakable. Nobody onboard considered that device absence as a capital default.

\subsection{Altimeter}

The knowledge of the flight height was indispensable in the case of flight over the sea. Knowing the flight height it was possible to obtain the depression correction in order to apply it into the heights obtained by the sextant. In the first 20 meters of height, this value ranged from 0' to 8'; at 200 meters of height this variation was only 1 '. The aneroid altimeter used on this flight was graduated every 10 meters up to a 2600 meters ceiling. Due to trust that all the crew had on this device, they decided never exceed that ceiling. Almost always the flight was conducted at much lower heights. While performing the astronomical observations the aircraft flew between 20 and 40 meters height; at this range the depression correction varied only 3'. Admiral Gago Coutinho had also recommended a process which he had used successfully in the First Aerial Crossing of the South Atlantic that consisted of measuring (by sextant or telemetric binoculars) the airplane shadow projected on the sea surface, a process only suitable when the height of the Sun was above $30^{\circ}$. Given this proposition, the height of the flight was given by Equation (1):

$$
A=C \sin ^{2} \alpha \operatorname{cotg} \delta
$$

where:

$A \leftrightarrow$ Height Requested; $C \leftrightarrow$ Shadow Length (constant);

$\alpha \leftrightarrow$ Sun Height; $\delta \leftrightarrow$ Shadow Angle.

The crew quickly built a table that based on function the input values $\alpha$ and $\delta$ immediately solved and gave the requested height in meters. This process was also used to assess the altimeter indications which depended on the atmospheric pressure variations.

\subsection{Chronometer}

Onboard there were three small diameter chronometers Ditisheim known by the des montres torpilleurs designation. Two of these chronometers were regulated by Greenwich Mean Time and the third device was regulated by sidereal time, which provided great assistance for stars or planets observations. There was also onboard a watch with three pointers: hours, minutes and seconds. This watch had been graduated by the crew in divisions of $1 / 10^{\text {th }}$ minute, thus enabling faster calculations. All those chronometers were tested before and after the journey: at Lisbon and at the Observatório do Rio de Janeiro. In these tests all chronometers worked perfectly; instead onboard, their measurements were absolutely unacceptable revealing a lack for shock and shake protection and especially during some considerable and sudden changes of temperature. Admiral Coutinho had even advised the crew for the board of a special watch that only counted minutes (ex: instead of marking $19 \mathrm{~h} 36 \mathrm{~m} 18 \mathrm{~s}$, this watch would mark simply 1176.3 minutes-later, the crew stated that it would have been a huge advantage the time counting in a single unit), however before the departure time was considered that would require a special provision and disposition of the tables.

\subsection{Sextant}

The description of the "System Admiral Gago Coutinho" sextant was repeatedly made at conferences, magazines, brochures not only by the occasion of the First Crossing of the South Atlantic, such as beyond. Onboard the "Argos" there was three sextants manufactured in different countries: England, France and Germany. (The Navy sextant could not be applied to aviation due to the difficulty of the definition of the sky-line at a normal 
flight altitude. Admiral Gago Coutinho developed a new sextant model suitable to measure the altitude of a star without the need of the sea horizon, named "precision sextant". This device had an artificial horizon line which was defined with the help of a water bubble. In February of 1969 by the Admiral Coutinho's centenary birth, the Apollo-8 Commander Frank Borman travelled to Portugal. He gave a lecture at the National Laboratory of Civil Engineering, where he explained that the Gago Coutinho principle was onboard the Apollo-8 flight. In fact, "a sextant used in aeronautics for the first time in the world by the Portuguese genius" was assembled to a telescope. He detailed that these instruments was connected to a computer, which indicated that the final accuracy error was 0.001 degree (Cardoso, 1981). In 1971, Francis Millet Rogers, from Harvard University wrote a book entitled "Precision Astrolabe; Portuguese Navigator and Transoceanic Aviation" published at Lisbon by the Academia Internacional da Cultura Portuguesa, and distributed in the U.S.A. by W. S. Sullwold, Tauton, Mass. In 1973, Colter, H. C. publishes his work entitled "An Early Portuguese Contribution to Air Navigation", in the Journal of Navigation (Vol. 26, No. 03, DOI: http://dx.doi.org/10.1017/S0373463300030010). In this paper, the author made references to Coutinho's process of navigation "which made the calculations on the eve of the flight so that the line position was drawn in the flight chart map, nearly 5 minutes after the end of observation, and while crossing the Atlantic South, close to equator line, this time was reduced to 3 minutes”; an unprecedented simplification studied by Coutinho (Cardoso, 1981).

\subsection{Protractors}

The crew had three protractors at their disposal: a $360^{\circ}$ protractor used for direct measurement of the course directions on the chart map; a $180^{\circ}$ protractor used to draw the course directions given in the chart map and a third, divided from $0^{\circ}$ to $90^{\circ}$ in all quadrants. This protractor was very useful for quick draws of height straight-lines "recta das Alturas" in a special chart map used during the celestial navigation. The two lines division intersecting in a right angle at the center of the protractor's center scale represented 10 miles adopted by chart map, or 1 millimeter by $4 \mathrm{~km}$. The use of this protractor was made together with a small ruler with divisions every $10 \mathrm{~km}$ from the chart map at the same scale.

\subsection{Books and Tables}

The navigational literatures onboard were the following books and tables: Nautical Almanac, Ball Tables (3 Volumes), Azimuths Tables (2 volumes), Mathematical Chambers Tables and a collection of hand written tables placed at visible points and easily query.

\section{First Aerial South Atlantic Night Crossing}

After making a strategic decision to follow the clockwise direction due the prevailing winds, the final Journey plan included stopovers at Casablanca, Vila Cisneros and Bolama (Guinea). Once at Bolama, the decision was to make an all at once Atlantic Crossing from Bolama to Natal (Brazil). The next stopover would be Rio de Janeiro, following ahead to Argentina and Chile, in order to complete the 12,000 km first leg of this Around the World Flight Attempt.

\subsection{First Flight Stage: Alverca $\Rightarrow$ Casablanca}

On 2 March the airplane's engine was put to work at 13:11 h, with the aim to start this first stage to Casablanca (All presented times in the Journey logbook was at GMT-Greenwich Mean Time). After a run of 600 meters the airplane with a total cargo weight of $2430 \mathrm{Kg}$ (see Table 1) took off without difficulty from Alverca (38 $53^{\prime} \mathrm{N}$ $\left.9^{\circ} 02^{\prime} \mathrm{W}\right)$. Jorge Castilho signed the take-off time in the logbook: 13:21 h. At 13:41 h the pilots flew over the Espichel Cape, $\left(38^{\circ} 24^{\prime} \mathrm{N} 9^{\circ} 13^{\prime} \mathrm{W}\right)$ following the route to St. Vincent Cape. At 14:35 h the crew flew over the St. Vincent Cape $\left(37^{\circ} 1^{\prime} \mathrm{N} 8^{\circ} 59^{\prime} \mathrm{W}\right)$, starting the flight over the Atlantic Ocean. The crew flew about two hours without land sighting. Jorge Castilho observing the Sun obtained a height straight-line that provided the necessary course correction. At 16:51 h, the crew sighted land. They approached the African Continent coast and at 17:51 h they overflew the location of this first stage: Casablanca. Due to the ships accumulation verified in the port of this city, Sarmento de Beires made two broad turns to study the water landing maneuver, which ran smoothly. A total of $650 \mathrm{~km}$ were flown in this first stage of the trip. During this stage the airplane spent 190 liters/hour of fuel and 4 liters/hour of oil. The maximum altitude reached was 200 meters and the average speed 
Table 1. Total initial cargo weight distribution at the first stage from Alverca to Casablanca.

\begin{tabular}{cc}
\hline 02 March $1927-1^{\text {st }}$ Stage Flight: Alverca $\Rightarrow$ Casablanca & $1880 \mathrm{~kg}$ \\
Crew (including clothes) & $300 \mathrm{~kg}$ \\
Oil & $110 \mathrm{~kg}$ \\
Navigation Equipment & $20 \mathrm{~kg}$ \\
Tools and Spare Parts & $60 \mathrm{~kg}$ \\
Supplies, Potable Water and Luggage & $40 \mathrm{~kg}$ \\
Hydroplane's Mast and Sail & $20 \mathrm{~kg}$ \\
Total Cargo Weight & $2430 \mathrm{~kg}$ \\
\hline
\end{tabular}

was $174.7 \mathrm{~km} / \mathrm{h}$ (Beires, 1927). Table 1 illustrates the total cargo weight distribution aboard the seaplane at first flight stage departure.

\subsection{Second Flight Stage: Casablanca $\Rightarrow$ Vila Cisneros}

On March 4 the crew performed the second stage of this journey. They took off at 7:30 $\mathrm{h}$ from Casablanca $\left(33^{\circ} 34^{\prime} \mathrm{N} 7^{\circ} 36^{\prime} \mathrm{W}\right)$. They overflew Mazagan (currently known as ElJadida, $33^{\circ} 15^{\prime} \mathrm{N} 8^{\circ} 30^{\prime} \mathrm{W}$ ), Azamor and Cantin Cape $\left(32^{\circ} 36^{\prime} \mathrm{N} 9^{\circ} 20^{\prime} \mathrm{W}\right)$. At 08:48h the crew loses the African coast sighing. At 10:21 h the crew sighted the Spanish Fort at Cape Juby $\left(27^{\circ} 56^{\prime} \mathrm{N} 12^{\circ} 55^{\prime} \mathrm{W}\right)$. After an astronomical observation madeby Jorge Castilho, they found that their speed was $170 \mathrm{~km} / \mathrm{h}$. At 14:55 h they overflew the Punta Elbow and an hour later they already overflew the Dakhla peninsula. At 15:25 h the seaplane pilots water landed at Villa Cisneros (currently known as Dakhla, Western Sahara, $23^{\circ} 42^{\prime} \mathrm{N} 15^{\circ} 57^{\prime} \mathrm{W}$ ). This stage (7:48 h of flight time) was piloted almost entirely by Sarmento de Beires. They observed that during this stage, the airplane increased its fuel and oil average consumptions for 195 liters/hour and 4.5 liters/hour, respectively. The maximum altitude reached was 800 meters and the average speed was $182.1 \mathrm{~km} / \mathrm{h}$. The engine worked at $1700 \mathrm{rpm}$ regime during about two hours and worked at $1650 \mathrm{rpm}$ regime for the rest of the flight (Beires, 1927). The third stage of this trip was planned for the 5 March; however the weather conditions that day postponed the travel plans.

\subsection{Third Flight Stage: Vila Cisneros $\Rightarrow$ Bolama}

The undulation was quite strong and the Badin pointer indicated sometimes wind gusts of $70 \mathrm{~km} / \mathrm{h}$. There was another setback with the sextant: the level was broken and Jorge Castilho brought the device to land to be repaired (Beires, 1927). On 6 March, the seaplane took off from Villa Cisneros at 7:31 h with destination to the city of Bolama, Guinea (Journal Flight, 1927b: p. 151). On leaving Villa Cisneros, the seaplane was enveloped in a sand cloud. At this point the crew noticed that the Badin device became inoperable. Minutes later, the airplane overflew the Barbas Cape following the lead of the Port-Etienne, Mauritania (French name for the city of Nouadhibou, $20^{\circ} 56^{\prime} \mathrm{N} 17^{\circ} 2^{\prime} \mathrm{W}$ ). In this route, the crew found that their average speed was over $180 \mathrm{~km} / \mathrm{h}$. Later the seaplane flew in a zone of turbulence with strong wind gusts. The pilots raised the airplane route to 800 meters however they could not escape from that turbulent region. At 8:40 h the pilots flew without land sighting and started to experience serious difficulties in maintaining a horizontal flight because they have no reference points to provide them with a horizontality notion. Minutes later the pilots spotted Saint-Louis $\left(16^{\circ} 02^{\prime} \mathrm{N}\right.$ $16^{\circ} 30^{\prime} \mathrm{W}$ ) and found that their position was about $20 \mathrm{~km}$ south of this city. Later, they spotted both Dakar and Goree Island $\left(14^{\circ} 40^{\prime} \mathrm{N} 17^{\circ} 24^{\prime} \mathrm{W}\right)$. At 15:50 they overflew over the Jeta Island, Guinea $\left(11^{\circ} 54^{\prime} \mathrm{N} 16^{\circ} 15^{\prime} \mathrm{W}\right)$. At this time they found that the radiator water had risen to $85^{\circ} \mathrm{C}$. At $15: 53 \mathrm{~h}$ the pilots sighted the lighthouse of Bolama $\left(11^{\circ} 35^{\prime} \mathrm{N} 15^{\circ} 28^{\prime} \mathrm{W}\right)$. Minutes later the crew water landed again in Portuguese territory. It was then completed the third stage of this trip, which $1490 \mathrm{~km}$ were flown at an average speed of $176.7 \mathrm{~km} / \mathrm{h}$. The fuel and oil consumption were within the values previously obtained, respectively 192 and 4.5 liters/hour (Beires, 1927). The "Argos" (Figure 4) had arrived to Portuguese territory in Africa.

\subsection{Failed Attempts to Take-Off from Bolama}

On 7 March the crew started all the preparations for the Atlantic Crossing stage. They roamed the island in 


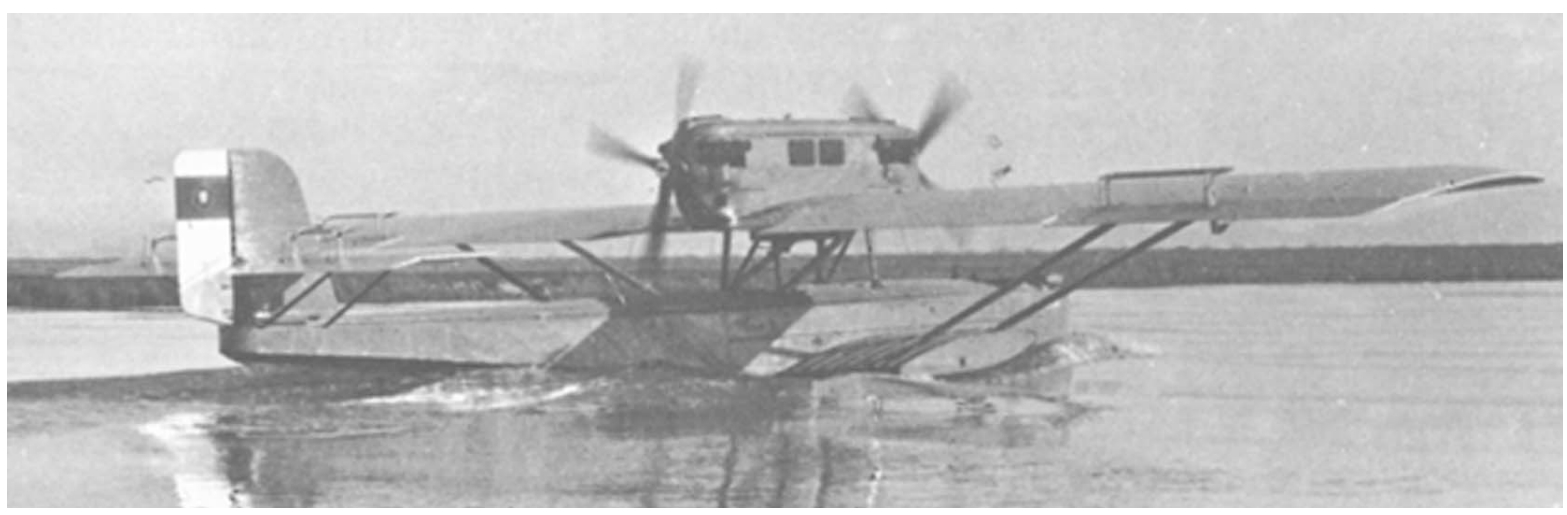

Figure 4. Photo of the "Argos" seaplane, revealing its double engines castle and the two propellers and the Portuguese flag painted at the rear.

search for the best place to take-off. Manuel Gouveia and Duvalle Portugal spent all the day preparing the seaplane. Jorge Castilho spent hours studying the tables which had to be prepared for night navigation. On 8 March at 14:00 $\mathrm{h}$ the airplane was ready to begin another stage of the journey, with a total load of $3372 \mathrm{~kg}$, from which $2780 \mathrm{~kg}$ were canned fuel. At 22:00 h that day the crew had already tried five unsuccessfully take-offs. On 9 March at 14:00 h, the crew made another take-off attempt this time with $3259 \mathrm{~kg}$ total load. At 23:00 h the crews made three take-off attempts again without success. On 10 March the crew tried one more take-off that failed, with a total load of $3100 \mathrm{~kg}$. Due to this situation, one of the crew members decided to sacrifice his personal involvement in the name of collective participation. Duvalle Portugal offered himself to stay at Guinea and thus try to avoid the unfeasibility of the journey. On 11 March at 00:00 h the crew tried five unsuccessful attempts to take-off, interspersed with long minutes of rallenti allowing the engine's cooling. In those attempts the engines worked from 1.5 to 3 minutes with the radiator water temperature exceeding the $100^{\circ} \mathrm{C}$ (Beires, 1927). On 11 March at 17:30 h and with less one crewmember (Journal Flight, 1927c: p. 163; Beires, 1927) the seaplane took off with some difficulty, with a total $3600 \mathrm{~kg}$ of fuel onboard. The behavior of the aircraft revealed to be quite good, with the engine working at a regime of $1680 \mathrm{rpm}$. In this perspective the crew had about eighteen flight hour (with consumption of 200 liters/hour). They thought that it would be very risky try to reach Natal, Brazil. When they had just flown about $100 \mathrm{~km}$ (45 minutes), Manuel Gouveia found that the fuel onboard was $3400 \mathrm{~kg}$. The fuel consumption was above all expectations. At this time the crew decided return to Bolama. However, it was already dark night and crew decided to alight the seaplane on the nearest island (Soga, Guinea) to avoid the navigation between islands at night. Then the crew went through some hectic days but managed to contact the Portuguese Government and explain what happened. On 16 March the crew received a telegram from Government of Portugal stating that the journey would have to continue its course to Rio de Janeiro at least and once there, the crew would have to wait for further instructions (Beires, 1927).

\subsection{Fourth Flight Stage: Night Atlantic Crossing: Sogá $\Rightarrow$ Fernando de Noronha Islands}

On 16 March the crew arrived onboard the seaplane at 17:20 hand at 19:08 $\mathrm{h}$ the seaplane took off. The navigator began its work with Venus observation at 43 minutes of flight. At 21:16 h the Canopus star at SW provided a height straight-line whose intersection with another height straight-line drawn from the Moon's observation provided the airplane position at $8^{\circ} 32^{\prime} \mathrm{N} 17^{\circ} 45^{\prime} \mathrm{W}$ and revealing an average speed of $143 \mathrm{~km} / \mathrm{h}$. At 22:27 h a Moon observation provided an indication of slight average speed increase and at 23:07 $\mathrm{h}$ the height straight-lines between Canopus star and Moon provided their position at $7^{\circ} 36^{\prime} \mathrm{N} 19^{\circ} 55^{\prime} \mathrm{W}$ and provided also their track way. After a few minutes Manuel Gouveia climbed up to the engines castle and when he sat down, wrote in the logbook that he had turned off one of the pumps feeding the rear engine, because it had stopped working. At 23:55 h Sarmento de Beires requested to the crew some flight data. The speed was $142 \mathrm{~km} / \mathrm{h}$, the traveled distance was about $850 \mathrm{~km}$, and the total fuel consumption was 1136 liters at a rate of 195 liters/hour. At 0:09 h on March 17 another height straight-line crossing by Sirius and Spica, revealed their position at $7^{\circ} 18^{\prime} \mathrm{N} 21^{\circ} 12^{\prime} \mathrm{W}$ and an average speed of $136 \mathrm{~km} / \mathrm{h}$ (Cardoso, 1981). At 01:54 h and by observing the Moon, the height straight-line crossing provided their position at $5^{\circ} 52^{\prime} \mathrm{N} 23^{\circ} 05^{\prime} \mathrm{W}$ and an average speed of $148 \mathrm{~km} / \mathrm{h}$. Minutes later Jorge Castilho was 
deprived of his astronomical observations due to overcast crossing. At 02:48 h the pilots began to observe clouds on the horizon. Minutes later they were wrapped in black masses with sprinkles. Moments later Manuel Gouveia rose suddenly and climbed up to the engines castle. At that moment there was an orange flame that flowed in sparkling jets accompanying with strong engine sound failure at the forward engine. A clamp fuel pipe had broken. The engine had been poorly fed and had some carburetor returns. The mechanic prompt intervention had freed all the crew from a forced night sea land at an uncertain sea. At 03:30 h a new immediate mechanic intervention at a water pipeline solved once more a new engine failure. At 04:00 h the seaplane became completely involved by showers. At 04:37 h Jorge Castilho had the chance of a new astronomic observation. By the Arcturus star and the Moon height straight-line crossing their new position was at $3^{\circ} 55^{\prime} \mathrm{N} 26^{\circ} 23^{\prime} \mathrm{W}$ at an average speed of $156 \mathrm{~km} / \mathrm{h}$ since the last observation at 01:54 h. Their position was about $100 \mathrm{~km}$ to north of their requested route, an error mostly due to the violent and swirling atmosphere on their path. At 05:31 h they found a new position at $3^{\circ} 00^{\prime} \mathrm{N} 27^{\circ} 15^{\prime} \mathrm{W}$. This position placed them at $330 \mathrm{~km}$ distance from Saint Peter and Saint Paul Archipelago, which they overflew shortly after the dawn. At 09:12 h the seaplane crossed the equator line. At 11:04 h a height straight-line provided a $25 \mathrm{~km}$ diversion relative to Fernando Noronha Island route. This distance at a $150 \mathrm{~km} / \mathrm{h}$ speed took 10 minutes travel. At that moment Sarmento de Beires requested to the crew some flight data. Their remaining fuel was 500 liters and they were at about $200 \mathrm{~km}$ from Fernando de Noronha $\left(3^{\circ} 51^{\prime} \mathrm{S} 32^{\circ} 25^{\prime} \mathrm{W}\right.$ ) and $600 \mathrm{~km}$ from Natal. With this information the crew lost his hope of reaching the city of Natal. At 11:14 h, Jorge Castilho sat beside Sarmento de Beires and spun the compass limbo $46^{\circ}$ south of its previous course. They had decided to change course towards Fernando de Noronha. At 12:00 h it was made one final observation to the Sun which provided a west $20 \mathrm{~km}$ detour of this course. This error caused by the wind was corrected. At 13:05 h the crew had visual contact with his new destination. At 13:20 h the seaplane "Argos" touched the sea at the San Antonio bay on Fernando de Noronha Island. A total of $2595 \mathrm{~km}$ were flown in a flight time of 18:12 h at an average speed of $143.4 \mathrm{~km} / \mathrm{h}$. The average of fuel and oil consumption was $192 \mathrm{li}-$ ters/hour and 4.5 liters/hour, respectively. The seaplane finished this stage with 130 liters of fuel available in its fuel tank (Beires, 1927). The British press reported that successful completion of the 16-17 March overnight flight across the South Atlantic (Journal Flight, 1927d: p. 176). Manuel Gouveia saved the crew at least from twice forced sea landings in two interventions due engine failures during the flight. The maximum altitude during this stage was 900 meters. The unwavering confidence of the crew in their navigation methods (without radio goniometry or telegraphy devices onboard) had allowed them to navigate more than $2000 \mathrm{~km}$ throughout a dark night across the Atlantic Ocean, and find a route that took them to overfly the islets with a total area of about 13,000 $\mathrm{m}^{2}$ (Figure 5) - the greatest victory of aerial celestial navigation (Corrêa, 1969). Jorge

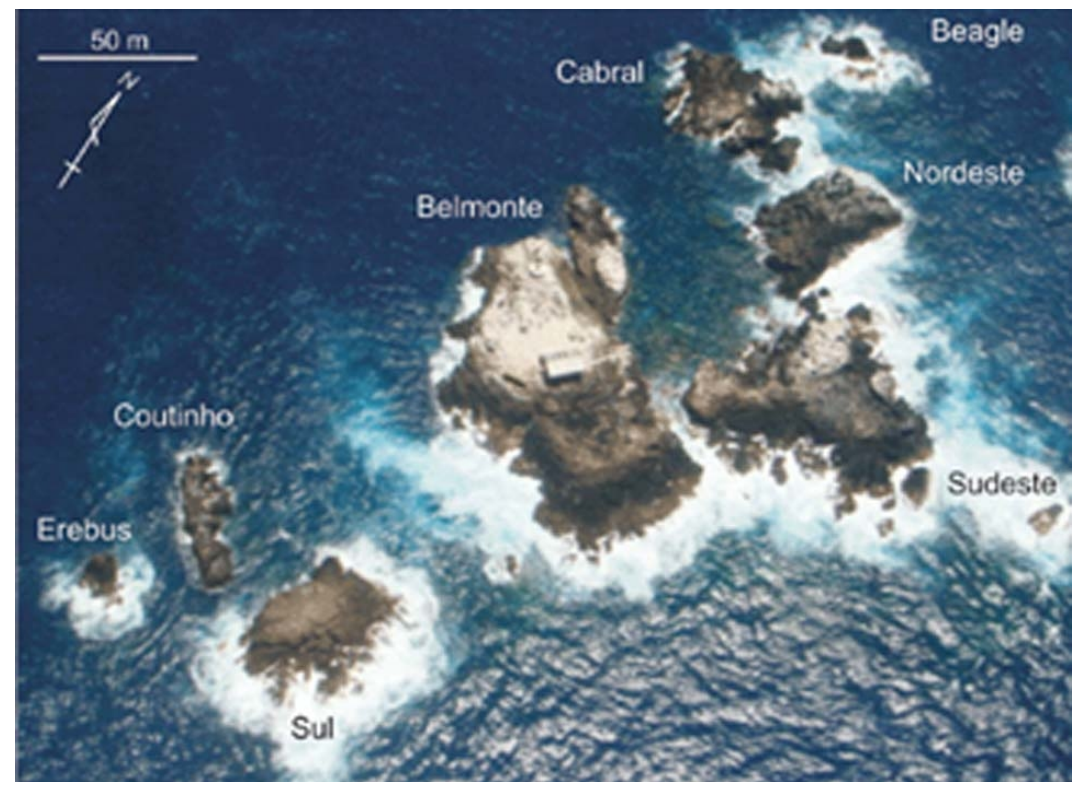

Figure 5. The Saint Peter and Saint Paul archipelago with a total area of $0.013 \mathrm{~km}^{2}$ and the respective scale of $50 \mathrm{~m}$. 
Castilho had just performed an unprecedented feat worldwide thus affirming the value of the Admiral Gago Coutinho sextant. Jorge Castilho wrotein his report: “... Creio que foi a primeira vez que um avião passou uma noite inteira a voar sobre o mar e sem ter para se orientar outro recurso além dos processos astronómicos que se mostrou serem absolutamente praticáveis e dignos de confiança...”; "[...I believe it was the first time that an airplane flew an entire night over the ocean having for its guidance resources only astronomical processes which proved to be absolutely feasible and trustworthy...]. Portraits of this crew are illustrated on Figure 6. By regarding the nighttime aviation records, it is a fact that Sarmento de Beires's flight made History when he made the World's first aerial night time transatlantic crossing, just one month before the non-stop flight across the Atlantic from New York to Paris, by Charles Lindberg.

\subsection{Fifth Flight Stage: Fernando de Noronha Islands $\Rightarrow$ Natal}

On 18 March after the 800 liters refueling the seaplane took off from Fernando de Noronha to the city of Natal $\left(05^{\circ} 47^{\prime} \mathrm{S} 35^{\circ} 2^{\prime} \mathrm{W}\right)$, a stage of $390 \mathrm{~km}$ that took 2:24 h flight time. The weather was stupendous. After two turns broad the city the seaplane alighted in front of Natal, before a crowd of about 5000 people. After this delirium they were received by the Governor, followed by speeches, banquets, dances, new speeches and an immensity of telegrams including one with the Gago Coutinho's congratulations. From all the Portuguese Colonies and also form all the Brazilian coast cities emerged requests asking for a crew visit (Beires, 1927). On 19 March the seaplane was refueled with 2200 liters, the necessary fuel to the Natal-Rio de Janeiro stage flight. However, on 20 March at 03:00 h the crew received a permit from the Directorate of Aeronautics Weapon with instructions to make extra stopovers at Recife and the Baía (Table 2). This authorization amounted to a formal order. The Directorate of Aeronautical Weapon had also authorized the journalist Mário Melo travelling aboard the "Argos" in the stage flight Natal-Recife. On this stage would also travel aboard the reporter Mário Coutinho.

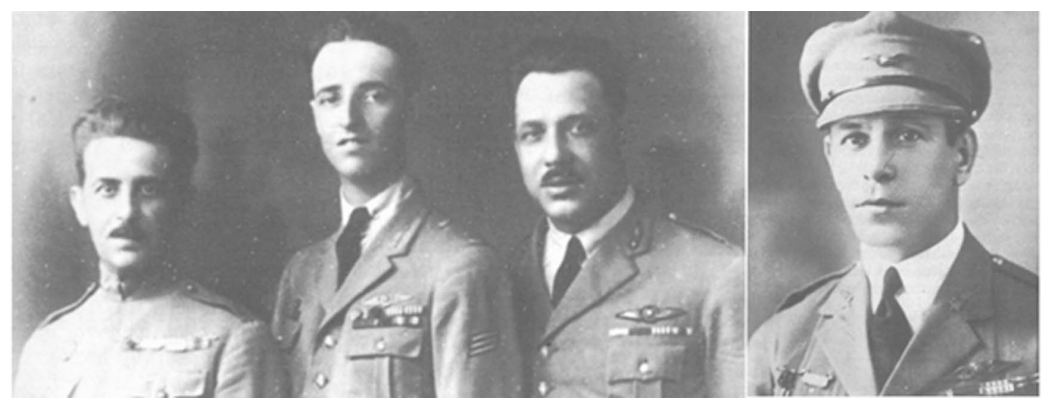

Figure 6. The “Argos” seaplane crew members: from left to right) Jorge Castilho (navigator); Sarmento Beires (pilot); Manuel Gouveia (mechanic) and Duvalle Portugal (second pilot).

Table 2. Resume of the itinerary Journey of the first aerial south Atlantic night crossing.

\begin{tabular}{|c|c|c|c|}
\hline \multicolumn{4}{|c|}{ Itinerary Journey } \\
\hline 1927 & Stages & Flown Distance (km) & Flight Time (h:m) \\
\hline 02 March & Alverca $\Rightarrow$ Casablanca & 650 & $3: 43$ \\
\hline 04 March & Casablanca $\Rightarrow$ Vila Cisneros & 1420 & $7: 48$ \\
\hline 06 March & Vila Cisneros $\Rightarrow$ Bolama & 1490 & $8: 26$ \\
\hline 11 March & Bolama $\Rightarrow$ Sogá & 150 & $1: 05$ \\
\hline 16 March & Sogá $\Rightarrow$ Fernando de Noronha & ------- & ------- \\
\hline 17 March & Sogá $\Rightarrow$ Fernando de Noronha & 2595 & $18: 12$ \\
\hline 18 March & Fernando de Noronha $\Rightarrow$ Natal & 390 & $2: 24$ \\
\hline 20 March & Natal $\Rightarrow$ Recife & 280 & $1: 50$ \\
\hline 07 April & Recife $\Rightarrow$ Baía (S. Salvador) & 700 & $5: 10$ \\
\hline \multirow[t]{2}{*}{10 April } & Baía (S. Salvador) $\Rightarrow$ Rio de Janeiro & 1350 & 9:17 \\
\hline & Total & 9025 & $58: 05$ \\
\hline
\end{tabular}




\subsection{Sixth Flight Stage: Natal $\Rightarrow$ Recife}

On 20 March at $07: 00$ h the seaplane took off from Natal towards Recife $\left(08^{\circ} 03^{\prime} \mathrm{S} 34^{\circ} 52^{\prime} \mathrm{W}\right)$ with a payload of $2420 \mathrm{~kg}$. During the stage the weather was always beautiful, but Sarmento de Beires traveled furious, mainly due to the behavior of the distraught journalist. After sea land, and when they were covering the engines, Manuel Gouveia and Mário Coutinho found that the rear propeller was destroyed. This accident involved a two-week delay in their next stage. The Brazilian Naval Aviation offered the disposal of all propeller models that they had for usage, unfortunately none of them proved to be adaptable. The same happened with the offer of the Uruguayan Consul. On 2 April, new propellers came aboard the ship Zeelandia from Buenos Aires. On the same day one propeller was calibrated and engaged at the engine by Manuel Gouveia. The airplane was ready to continue their journey the next morning. Sarmento de Beires was worried because during those immobility days a huge amount of dirt mainly composed by marine life was glued to the boat-hull fuselage. On 3 April at 07:00 h and at 10:00 h the crew tried to start a new stage of the journey, unfortunately without success. They decided to postpone the stage in order to clean the boat-hull fuselage and to check the propeller income power, since the total load onboard was now $2000 \mathrm{~kg}$. On 4 April at 11:00 h the airplane had already its boat-hull fuselage cleaned and a new propeller engaged at the engine and was already set to afloat at the sea. On 5 April, with a total load of $1800 \mathrm{~kg}$ all take-off attempts were thwarted off. The same happened on 6 April.

\subsection{Seventh Flight Stage: Recife $\Rightarrow$ Baía (S. Salvador)}

On 7 April, with only $1450 \mathrm{~kg}$ full load at $07: 53 \mathrm{~h}$ the seaplane took off with great difficulty flying the first 25 minutes under very strong downpours. The flight height was carried out between 100 and 500 meters. At 09:25 h they overflew the city of Maceio $\left(9^{\circ} 39^{\prime} \mathrm{S} 35^{\circ} 44^{\prime} \mathrm{W}\right)$. At 12:15 h they had visual contact with the immense bay of S. Salvador $\left(12^{\circ} 58^{\prime} \mathrm{S} 38^{\circ} 30^{\prime} \mathrm{W}\right)$ where they arrived at 12:41 h. The crew was received euphorically with sirens whistles and abundant crackling fireworks. Table 2 presents a resume of flight stages, flown distances and flight times along all Journey of First Aerial South Atlantic Flight Time.

\subsection{Eighth Flight Stage: Baía (S. Salvador) $\Rightarrow$ Rio de Janeiro}

Finally on 10 April at 06:52 h the seaplane took off with the destination to Rio de Janeiro. At 09:49 h the crew overflew Santa Cruz, the place where the Pedro Álvares Cabral caravels had anchored 427 years before (Pedro Álvares Cabral, Belmonte, Portugal, 1467-1520, was a Portuguese nobleman, military commander, explorer and navigator, regarded as the discoverer of Brazil on April 22, of year 1500). At 11:06 h they overflew the city of Caravelas $\left(17^{\circ} 44^{\prime} \mathrm{S} 39^{\circ} 16^{\prime} \mathrm{W}\right)$. By their calculations, the seaplane was now approximately at $520 \mathrm{~km}$ from Rio de Janeiro, with an average speed of $130 \mathrm{~km} / \mathrm{h}$ in the last two flight hours. The available fuel onboard was 600 liters and the average consumption was 150 liters/hour. At 15:40 h the pilots sighted the Ancora Island ( $\left.22^{\circ} 46^{\prime} 15^{\prime \prime S} 41^{\circ} 47^{\prime} 22^{\prime \prime W}\right)$. Shortly after Jorge Castilho, recognizing the Rasa Island, gave information to Sarmento de Beires to curb to starboard. Seconds later flying at an altitude of 1000 meters, they step into the Guanabara Bay right in front of Rio de Janeiro (22 $\left.54^{\prime} \mathrm{S} 43^{\circ} 12^{\prime} \mathrm{W}\right)$. The "Argos" overflew the city escorted by Brazilian Naval Aviation aircrafts. In a slow spiral, the seaplane alighted in front of the Praia do Flamengo. In this stage with 9:17 h duration the pilots flew $1350 \mathrm{~km}$. The city's sky was full of whitish smoke from the rocket launch. The crew was received in apotheosis (Figure 7). During their stay at Rio de Janeiro the crew had the opportunity to receive a very important personality visit aboard the "Argos” (Figure 8).

\section{Rio de Janeiro $\Rightarrow$ Ilhéus $\Rightarrow$ Belém $\Rightarrow$ Atlantic Ocean (Seaplane Sunk)}

Also at 10 April the crew received an official telegram from the Portuguese Government suggesting their return to Portugal via Cape Verde and Madeira. Although it could not be found a written technical explanation about the decision of the Portuguese Government in order abdicate this dream of Air Circum-navigation Journey so laboriously engineered, the decision makers will eventually have canceled the project because they believe that the "Argos" would never have autonomy to overcome with success the distances of the stages at the Pacific; one of these stages consisted in a distance of $3084 \mathrm{~km}$ of straight flight (any deviation would increase such distance). As the government's pathway return suggestion was not recommended due to weather conditions reasons, Sarmento de Beires advised by Gago Coutinho chose to return to Portugal via North America, Newfoundland and Azores. On 5 June on the return journey, a few hours after having taken off from Belem $\left(01^{\circ} 27^{\prime} \mathrm{S} 48^{\circ} 30^{\prime} \mathrm{W}\right)$ 


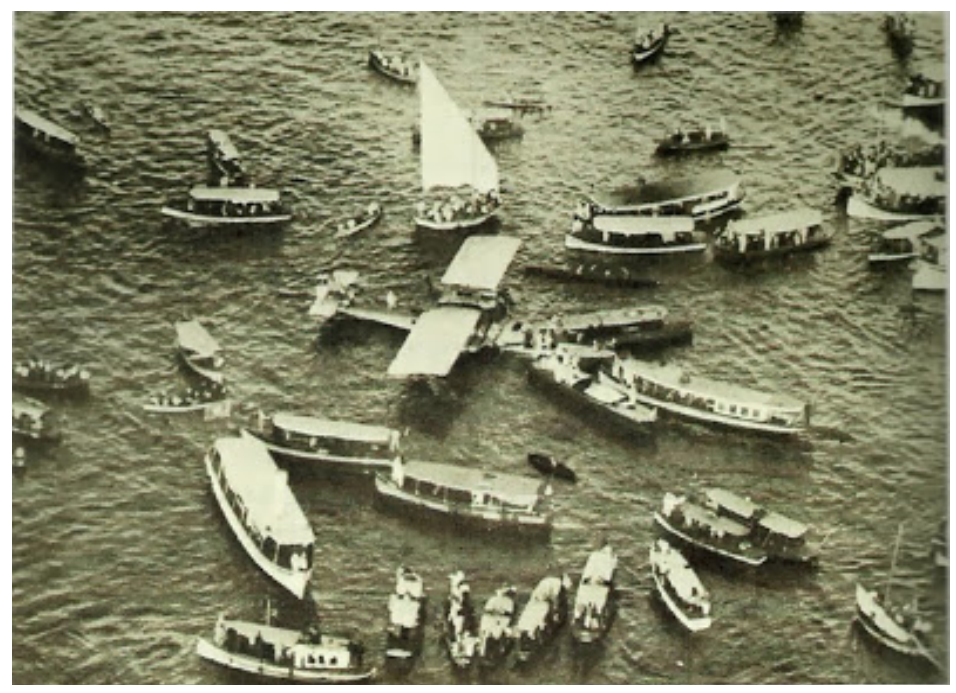

Figure 7. Panoramic photo of the seaplane “Argos” arrival at Rio de Janeiro with an apotheotic reception at Guanabara Bay.

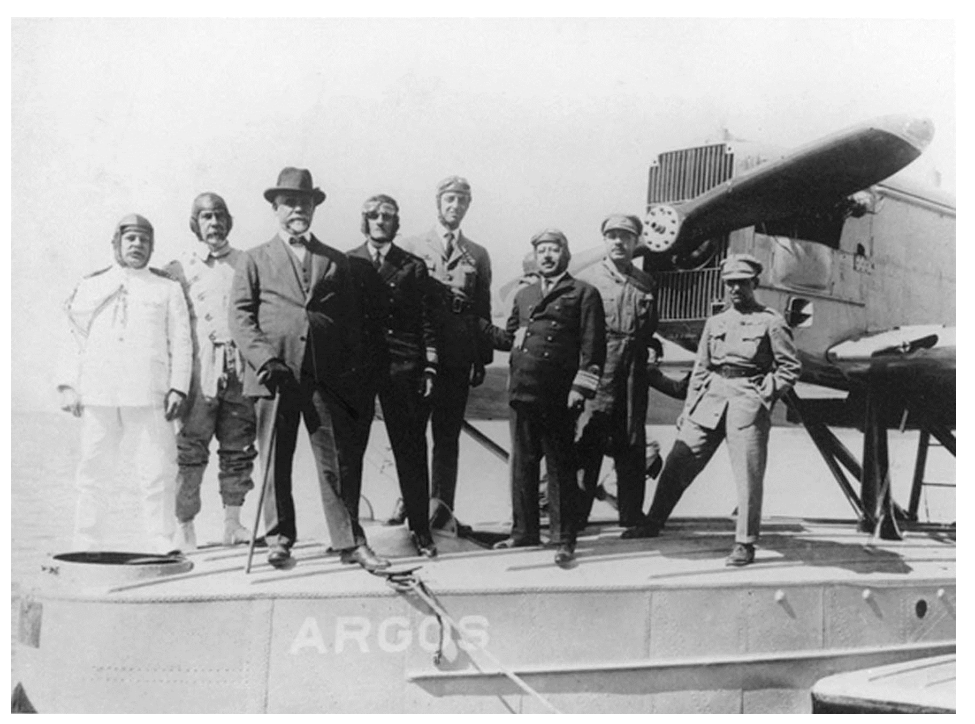

Figure 8. A photo of the crew onboard the "Argos" with the Brazilian President Washington Luiz and his delegation at Rio de Janeiro.

toward the Guianas, a large rip on the left wing forced one sea land emergency at the coordinate point $2^{\circ} 41^{\prime} \mathrm{N}$ $50^{\circ} 29^{\prime} \mathrm{W}$, about $40 \mathrm{~km}$ distance from land. The aircraft became unrecoverable due to a huge wave and capsized. Near sunset, Sarmento de Beires, Jorge Castilho and Manuel Gouveia were rescued by two fishermen (Journal Flight, 1927: p. 481). After taking off from Rio de Janeiro, the airplane flew $4510 \mathrm{~km}$ in a total flight time of 28:59 h. On 27 June 1927 the airmen arrived at Lisbon onboard the Hildebrand ship.

\section{Conclusion}

The introduction of the crossing ocean's air travels brought new challenges for air navigators, due to the difficulty to find their position in the air; and as some air navigators had an early exhaustive experience in sea navigation, they worked hard to adapt their very well-known nautical devices for aerial use. In 1922, for the first time in the aviation history, the crossing of the South Atlantic was achieved by the Portuguese navigators Gago Coutinho and Sacadura Cabral; this feat was achieved exclusively with the help of astronomical devices that allowed an accurate positioning of aircraft when flying over the ocean — with no reference points on the ground: 
a modified navy sextant and a course corrector; both devices were invented by those navigators. In the following years, the Admiral Coutinho's sextant was continuously improved by Gago Coutinho and Jorge Castilho in a way to enable overnight observations. The Portuguese aeronautics rejoiced auspicious days that time, with some aviation pioneers trying consecutively to reach more distant places along intercontinental flights. In 1923, Gago Coutinho and Sacadura Cabral were planning to perform an Around the World Flight, a dream pursued also by Sarmento de Beires in 1924 and 1927. Several Around-the-World Flight Attempts were made in 1924: United States, England, France, Portugal, Argentina and Italy. Due to the difficulty of this task, the circumnavigation purpose was only officially confirmed before the general public, when a considerable flying progress was achieved. This article pays tribute to the second Portuguese Around-the-World Flight Attempt in 1927; by following the knowledge obtained by Coutinho and Cabral, four Portuguese airmen (Sarmento de Beires, Jorge de Castilho, Manuel Gouveia and Duvalle Portugal) started an Around the World Flight Attempt in a mission that ended with seaplane sunk at the Ocean; however this mission became known in the World as the First Aerial South Atlantic Night Crossing. For the first time in aviation history, during the night of 16 to 17 March 1927, a Portuguese crew flew $2595 \mathrm{~km}$ (flight tome: 18:12h) over the Atlantic Ocean from Guinea, Africa to Fernando de Noronha Island, Brazil. The flight was exclusively achieved by astronomical processes navigation resources that proved again to be absolutely feasible and trustworthy, regardless day or night lighting level conditions. By regarding the nighttime aviation records, it is a fact that Sarmento de Beires's flight made history when he made the World's First Aerial Ocean Night Crossing.

\section{References}

Albuquerque, L. (1989). Curso de História da Náutica (Reprinted). Lisboa: Publicações Alfa.

Barata, J. M. M., Mendes, A. L. M., Morgado, C. M. P., Neves, F. M. S. P., \& Silva, A. R. R. (2009). Origins of Scientific Aircraft Navigation. Proceedings of the 45th AIAA/ASME/SAE/ASEE Joint Propulsion Conference \& Exhibit and 7th International Energy Conversion Engineering Conference 2009, Denver, 2-5 August 2009, 1974-1980. http://dx.doi.org/10.2514/6.2009-5022

Beires, J. S. (1927). Asas que naufragam: De como o avião Argos, ao fim de dezasseis mil quilómetros de vôo, se perdeu ao largo das costas da Clevelândia e do mais que durante a viagem se passou. $1^{\mathrm{a}}$ Edição, Lisboa: Livraria Clássica Editora de A. M. Teixeira \& $\mathrm{C}^{\mathrm{a}}$. (Filhos).

Beires, J. S. (1953). De Portugal a Macau (a viagem do “Pátria”). $2^{\mathrm{a}}$ Edição, Porto: Tipografia Domingos de Oliveira.

Cabral, S. (1921). Coutinho-Sacadura Course Corrector. Premier Congrés International de la Navigation Aérienne, Paris, 15-25 November 1921, 112-114. http://naca.central.cranfield.ac.uk/reports/1922/naca-tm-132.pdf

Cardoso, E. P. C. (1981). História da Força Aérea Portuguesa (Volume II). Lisboa: Edição Cromocolor, Lda.

Corrêa, P. (1964). Sacadura Cabral, Homem e Aviador. Edição do Autor, Lisboa: Bertrand.

Corrêa, P. (1969). Gago Coutinho, Precursor da Navegação Aérea. Edição do Centenário 1869-1969, Porto: Portucalense Editora.

Dollfus, Ch., \& Hirschauer, L. (1925-1926). L’année Aéronautique. Paris: Dunod (92, Rue Bonaparte).

Journal Flight (Official Organ of the Royal Aero Club of the United Kingdom) (1923). The Portuguese around the World Flight. 13 September 1923, 551.

Journal Flight (Official Organ of the Royal Aero Club of the United Kingdom) (1927a). A Portuguese World Flight. 24 February 1927, 98.

Journal Flight (Official Organ of the Royal Aero Club of the United Kingdom) (1927b). Portuguese World Flight. 10 March 1927, 151.

Journal Flight (Official Organ of the Royal Aero Club of the United Kingdom) (1927c). Portuguese World Flight. 17 March 1927, 163.

Journal Flight (Official Organ of the Royal Aero Club of the United Kingdom) (1927d). The Portuguese World Flight. 24 March 1927, 176.

Neves, F. M. S. P., Barata, J. M. M., \& Silva, A. R. R. (2010a). Gago Coutinho and the Aircraft Navigation. Proceedings of the 48th AIAA Aerospace Sciences Meeting Including the Horizons Forum and Aerospace Exposition 2010, Oriando, 4-7 January 2010, 1823-1832. http://dx.doi.org/10.2514/6.2010-156

Neves, F. M. S. P., Barata, J. M. M., \& Silva, A. R. R. (2010b). Sacadura Cabral and the Dawn of Portuguese Aviation. Proceedings of the 46th AIAA/ASME/SAE/ASEE Joint Propulsion Conference \& Exhibit 2010, Nashville, 25-28 July 2010 430-441. http://dx.doi.org/10.2514/6.2010-6544 
Neves, F. M. S. P., Barata, J. M. M., \& Silva, A. R. R. (2016). Sacadura Cabral and the Dawn of Portuguese Aviation. Open Journal of Applied Sciences, 6, 16-30. http://dx.doi.org/10.4236/ojapps.2016.61003

Reis, M., \& Cortesão, A. (1969). Gago Coutinho Geógrafo. Coimbra, Junta de Investigações do Ultramar, 1970, sep. de Memórias da Academia das Ciências de Lisboa, Tomo XIII.

Silva, A. R. R., Barata, J. M. M., Morgado, C. M. P., \& Neves F. M. S. P. (2009). First Flight from Europe to the South Atlantic. Proceedings of the 47th AIAA Aerospace Sciences Meeting and New the Horizons Forum and Aerospace Exhibit 2009, Orlando, Florida, 5-8 January 2009, 13670-13675. http://dx.doi.org/10.2514/6.2009-1162 